Intersections

Canadian Journal of Music

Revue canadienne de musique
Intersections

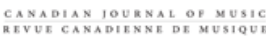

\title{
Report-Centre and periphery, roots and exile: Interpreting the music of István Anhalt and György Kurtág. Centre et périphérie, racines et exil : L'interprétation de la musique d'István Anhalt et de György Kurtág. Rozsa Centre, University of Calgary January 22-25 janvier, 2008
}

\section{Friedemann Sallis}

Volume 28, numéro 1, 2007

URI : https://id.erudit.org/iderudit/019296ar

DOI : https://doi.org/10.7202/019296ar

Aller au sommaire du numéro

Éditeur(s)

Canadian University Music Society / Société de musique des universités canadiennes

ISSN

1911-0146 (imprimé)

1918-512X (numérique)

Découvrir la revue

Citer ce compte rendu

Sallis, F. (2007). Compte rendu de [Report-Centre and periphery, roots and exile: Interpreting the music of István Anhalt and György Kurtág. Centre et périphérie, racines et exil : L'interprétation de la musique d’István Anhalt et de György Kurtág. Rozsa Centre, University of Calgary January 22-25 janvier, 2008]. Intersections, 28(1), 176-180. https://doi.org/10.7202/019296ar
Résumé de l'article

Au mois de janvier 2008, le département de musique de l'Université de Calgary a consacré trois jours à un colloque bilingue portant sur la musique et les idées d’István Anhalt et de György Kurtág, examinées sous les angles musicologiques, ethnomusicologiques, pédagogiques et analytiques. Des participants du Canada, d'Europe et des États-Unis ont présenté des communications et participé à des discussions entourant la musique, ainsi que l'identité et l'appartenance à un lieu des deux compositeurs, par le biais d'une large sélection d'oeuvres. La conférence d'ouverture d'Anhalt a abordé des considérations biographiques en rapport avec l'émigration de sa Hongrie natale et l'impact de cet événement sur sa musique, tandis que celle de Beckles Willson s'est concentrée sur le rapport intime qui lie la musique de Kurtág à Budapest. Les présentations subséquentes ont dévoilé de nouveaux aperçus sur la musique vocale des deux compositeurs et sur les oeuvres pour orchestre d'Anhalt et la musique de chambre de Kurtág. Le colloque s'est terminé avec des discussions parallèles concernant d'autres compositeurs, tels que B. Bartók, H. Lachenmann, J. Rea, W. Rihm, R. Schumann, M. Seiber et S. Veress. Six concerts ont aussi accompagné les débats avec des prestations d'oeuvres d’Anhalt, de Kurtág et d'autres compositeurs du Festival de la Nouvelle Musique 2008 du département de musique.
Tous droits réservés (C) Canadian University Music Society / Société de musique des universités canadiennes, 2007
Ce document est protégé par la loi sur le droit d'auteur. L’utilisation des services d’Érudit (y compris la reproduction) est assujettie à sa politique d'utilisation que vous pouvez consulter en ligne. 
REPORT-CENTRE AND PERIPHERY, ROOTS AND EXILE:

INTERPRETING THE MUSIC OF ISTVÁN ANHALT AND

György KurTÁg.

CENTRE ET PÉRIPHÉRIE, RACINES ET EXIL :

L'INTERPRÉTATION DE LA MUSIQUE D'IsTVÁN ANHALT ET

DE György KurtáG.

Rozsa Centre, University of Calgary

JANUARY 22-25 JANVIER, 2008

Friedemann Sallis

For three days during the last week of January 2008, the Department of Music of the University of Calgary hosted a symposium bringing together scholars from Europe and North America to examine how ideas of place and identity impinge on the creation and interpretation of music in the early 21 st century. The event was both bilingual (English-French) and intra-disciplinary; the expertise of the invited speakers covered a great breadth of interests in the field of music studies (including musicology, theory, ethnomusicology, music education, performance, and composition). All brought broad knowledge of twentieth-century music, notably Hungarian music, as well as deep understanding of the work of Anhalt, Kurtág, and numerous other composers to the event.

The primary objects of discussion were the work of István Anhalt (1919-) and György Kurtág (1926-). The former was born in Budapest. The latter was born in Lugoj, Romania to Hungarian parents (his birthplace being part of the Austro-Hungarian Empire until it was ceded to Romania in 1918). Kurtág spoke Hungarian at home and, from the age of six, Romanian at school. In 1946 he moved to Budapest, acquiring Hungarian citizenship in 1948. Both composers received diplomas from the Franz Liszt Academy (Budapest). Anhalt studied with Zoltán Kodály (1937-41), Kurtág with Kodály’s students: Sándor Veress (1946-8), briefly with Pál Járdányi, and then with Ferenc Farkas (1948-55). For both, the turbulent events of their youth had a profound impact on their careers. During the war, Anhalt, like other Jewish young men, was obliged to do forced labour for the Hungarian Army. Following the war he worked for a year as assistant conductor at the Budapest Opera (1945-6). In 1946 he went to Paris, where he studied composition with Nadia Boulanger and in 1949 immigrated to Canada, becoming a citizen in 1955. Since his arrival, Anhalt's contribution to music in Canada has been enormous. Little is known of Kurtág's wartime experience, though being Jewish, he, like Anhalt, was lucky to survive. During the 
traumatic months of the failed Hungarian revolution (1956), Kurtág considered leaving Hungary, as did many, including his friend and colleague György Ligeti. At the last minute Kurtág and his wife hesitated and as a result spent most of the next thirty years of their professional careers behind the iron curtain. Kurtág eventually took a position at the Franz Liszt Academy, where he went on to an illustrious career as professor of chamber music.

The Symposium began with two key-note presentations. For reasons related to his health, István Anhalt (Queen's University) could not attend and so his opening address was read by Alan Gillmor. In his text, Anhalt examined whether and to what extent the terms centre, periphery, roots, and exile can be legitimately applied to his career. In so doing he made a moving statement on his sense of identity and the various ways in which the idea of place can be related to his work. Rachel Beckles Willson (Royal Holloway) gave the second keynote address, entitled "Kurtág's Presence." Drawing on the work of Hans Ulrich Gumbrecht and Jean-Luc Nancy, she focused on the reception Kurtág's music has had in Budapest and how its "presence" in that place has evolved during the course of his career. Following this John Beckwith (University of Toronto) presented a character sketch of Anhalt based on fifty years of friendship and professional collaboration. The first session was brought to a close by Jean-Paul Olive (Université de Paris 8, Vincennes Saint Denis). In a lecture entitled "Le concept d'aura chez György Kurtág," Olive used Walter Benjamin's concept of 'aura' to better understand how the fragmentary form of Kurtág's music obtains cohesion and a sense of identity. The afternoon session began with a subtle presentation by Gordon E. Smith (Queen's University) on the "roots and routes" of Anhalt's operatic work. Alan Gillmor (Carleton University) took a close look at the numerous allusions to and quotations of Beethoven's music in Anhalt's Sonance-Resonance (Welche Töne?). The afternoon session finished with three papers on Kurtág's vocal music. Dina Lentsner (Capital University Conservatory of Music) and Julia Galieva-Szokolay (Glenn Gould School) examined Kurtág's settings of Russian poetry. Between these, Alvaro Oviedo (Université de Paris 8, Vincennes Saint Denis) presented new strategies for the analysis of Kurtág's Kafka Fragmente Op. 24.

The Thursday sessions provided opportunities to hear large excerpts and whole works by Anhalt and Kurtág. The morning session began with an archival recording of the first performance of Anhalt's Twilight Fire (Baucis' and Philemon's Feast) (2001) for orchestra, the first of three orchestral works written for the Kingston Symphony between 2001 and 2005. Robin Elliott (University of Toronto) then presented a paper on the Kingston Triptych and carefully explained how these compositions are linked to the place where they were written. This was followed by a recorded performance of The Tents of Abraham (A Mirage-Midrash) (2003) for which Anhalt was awarded a Juno Award in 2005. After the break, William Benjamin (University of British Columbia) spoke on the content of The Tents of Abraham and the world in which this message was received. Following Benjamin's paper, a lively discussion ensued on how Anhalt and his work can be related to a sense of place. Should they be situated primarily in their local context or should we not be thinking more broadly, so as to 
include the places where Anhalt received his training and worked before arriving in Kingston (Budapest, Paris and Montreal)? The afternoon began with two papers that looked at the work of Anhalt and Kurtág from an educational perspective. Austin Clarkson (York University) focussed on the reception of Anhalt's music and carefully explained how it can be linked it to the education of the creative imagination. Stephano Melis (Conservatorio di Musica "L. Canepa" di Sassari) followed with a discussion of the pedagogical aspects of Kurtág's Játékok [Games], which can be understood as a "voyage of discovery" for young piano students. The last three presentations of the day examined Kurtág's work from the perspective of the performer. Rosabel Choi (University of Calgary) looked at issues surrounding the reception of Kurtág's Hommage à R.Sch. Op. 15d (1990) for clarinet (and bass drum), viola and piano. Choi's presentation was preceded and followed by papers on the interpretative challenges of Kurtág's idiosyncratic notation by Roger Admiral (University of Alberta) on the one hand, and by Edward Jurkowski and Deanna Oye (University of Lethbridge) on the other.

The last day of the Symposium saw a broadening of discussion topics to include other composers and their work. The opening session, entitled "The presence of the past in contemporary music," began with Ulrich Mosch (Paul Sacher Foundation, Basel), who opened his paper by asking which presence of which past? Through a comparison of selected works by Kurtág, Wolfgang Rihm and Helmut Lachenmann, Mosch carefully explained the difference between allusion and quotation, and how these references function in contemporary music. In her paper entitled "Auto-construction et rayonnement du compositeur vus à travers les sources primaires conservées dans les Fonds István Anhalt," Rachelle Chiasson-Taylor (Bibliothèque et Archives Canada) presented an in-depth look at how the organization of a composer's surviving documents contributes to the construction of his or her legacy. Florian Scheding (Royal Holloway) compared the compositions and careers of Anhalt and Mátyás Seiber, and reminded his audience that when relating music to a sense of place, we must always clearly distinguish between the composer's work history and his or her biography. Scheding's paper reignited the previous day's animated discussion of how a sense of place can be related to a given composer's music. Kenneth DeLong (University of Calgary) closed the morning session with a paper entitled "Remembering the future: Canadian and Hungarian responses to the music of Robert Schumann," in which he showed how composers as different as Kurtág, R. Murray Schafer, Malcolm Forsyth and John Rea have reacted to Schumann's legacy.

The Symposium's last session focussed on "The migration of composers and their music." Péter Laki (Bard College) is one of a very few scholars who can speak authoritatively on both Anhalt and Kurtág and made use of this unique perspective to elucidate similarities and difference between the early careers of both. Tanya Hage (University of Calgary) turned once again to the The Tents of Abraham, looking for traces of musical styles from both the new and the old worlds in Anhalt's compositional technique. Christoph Neidhöfer (McGill University) looked at the work of Sándor Veress from a similar per- 
spective. Veress's move from Hungary to Switzerland in 1949 coincided with the appearance of a form of twelve-tone technique in his compositions. Daniel Fung (University of Calgary) performed excerpts and identified examples of similar composition technique in Anhalt's early Sonata for piano (1951) and Béla Bartók's Sonata for piano (1926). Finally Friedemann Sallis (University of Calgary) brought the Symposium to a close with an attempt at sketching the importance of memory in the work of Anhalt and Kurtág.

The Symposium was a remarkable success, a measure of which resides in the fact that it brought together two groups of scholars. Neither group knew the other or the other group's composer very well. By the end, those (mainly Canadians) who came to speak on Anhalt left with a clearer idea of Kurtág's oeuvre, while those (mainly from outside Canada) with expertise on Kurtág's work left with a better understanding of Anhalt's music and of the importance questions of place and identity can have here.

As well as three full days of lectures, the event also included a series of six concerts, which constituted the 2008 edition of the Department's New Music Festival, an annual occurrence at the University of Calgary for the past five years. Besides numerous works by Anhalt and Kurtág, these concerts also presented the first performances of works by Canadian composers David Eagle (1955-), Roger Feria (1980-) and Roberta Stephen (1931-); by Sardinian composers, Antonio Doro (1958-) and Franco Oppo (1935-); as well as the Canadian premiere of a work by the English composer Alan Edwards (1970-). The Symposium organizers are deeply indebted to Library and Archives Canada and the Paul Sacher Foundation (Basel Switzerland) for contributing high quality photographic reproductions of documents from the Anhalt Fonds and the György Kurtág Manuscript Collection, respectively. This resulted in a fine photo exhibition juxtaposing the careers and work of Anhalt and Kurtág. We warmly thank Michelle Arbuckle, Chief Librarian of the Canadian Music Centre, for organizing a presentation of Anhalt's manuscripts and scores held at the Centre, as well as his scores published by Berandol Music. Finally we are deeply grateful to the University of Calgary and especially Dean Ann E. Calvert and her staff at the Faculty of Fine Arts for their steadfast support.

\section{RÉSUMÉ}

Au mois de janvier 2008, le département de musique de l'Université de Calgary a consacré trois jours à un colloque bilingue portant sur la musique et les idées d'István Anhalt et de György Kurtág, examinées sous les angles musicologiques, ethnomusicologiques, pédagogiques et analytiques. Des participants du Canada, d'Europe et des États-Unis ont présenté des communications et participé à des discussions entourant la musique, ainsi que l'identité et l'appartenance à un lieu des deux compositeurs, par le biais d'une large sélection d'œuvres. La conférence d'ouverture d'Anhalt a abordé des considérations biographiques en rapport avec lémigration de sa Hongrie natale et l'impact de cet événement sur sa musique, tandis que celle de Beckles Willson sest concentrée sur le rapport intime qui lie la musique de Kurtág à Budapest. Les présentations subséquentes ont dévoilé de nouveaux aperçus sur la musique vocale des deux compositeurs et sur les œu- 
vres pour orchestre d'Anhalt et la musique de chambre de Kurtág. Le colloque s'est terminé avec des discussions parallèles concernant d'autres compositeurs, tels que B. Bartók, H. Lachenmann, J. Rea, W. Rihm, R. Schumann, M. Seiber et S. Veress. Six concerts ont aussi accompagné les débats avec des prestations d'œuvres d'Anhalt, de Kurtág et d'autres compositeurs du Festival de la Nouvelle Musique 2008 du département de musique. 